in acute rheumatism the micrococci, which are subendothelial, are rapidly destroyed, but the local lesions, the result of their virulence, do not disappear 'so readily. "The other difficulty is that of understanding malignant rheumatic endocarditis. When the diplococcus has sufficient virulence to destroy the surface endothelium of the valve and to live vigorously and persistently in the vegetation, then a simple becomes a malignant rheumatic endocarditis. Here, again, experiment and histological investigation enable one to link up the chain. We also showed that a deposit of fibrin, so often described in text-books, is no essential feature of a simple vegetation, which is at first entirely subendothelial.

I should like to read some account from the opponents of the view that rheumatic fever is due to the diplococcus of careful histological investigations such as Dr. Coombs is making. It is by these slow and prolonged studies that one learns very instructive points. For example, from a case of fatal chorea $I$ was once able to get a simple rheumatic endocarditis in the early active stage, and with Dr. Paine was able to demonstrate the micrococci in great numbers under the endothelium of the mitral valve, and also in great quantities in some minute blood capillaries at the base of the valve. Such a chance will probably not occur twice in a research lifetime, and is a striking support to Dr. Coombs's contention that the infection reaches the valves by the coronary circulation. Naturally I cannot admit that there is a single weak link in the chain of proof that the diplococcus is $a$, and probably the, cause of acute rheumatism. As to the specific nature of the diplococcus that is a different matter, but Dr. Coombs's investigations appear to me to strengthen the evidence in favour of there being some specific reaction produced in the tissues by this micro-organism.

I am, Sir, yours faithfully,

Harley-place, W., May 25th, 1909. $\quad$ F. J. PoYnTon.

\section{"RADIUM APPLICATORS" IN PRACTICE.}

To the Editor of THE LANCET.

SIR, - With reference to the idea that in order to gain the full effect of a radium salt it is necessary to spread it over the surface of an applicator in a mixture of varnish, as is described to be the present mode of use at the Paris Radium Institute, is it absolutely certain that such a procedure is necessary - or even advantageous-in the practical use of a radium salt for varied purposes?

In the treatment of skin affections where the affected area is extensive and little penetration is required, a rectangular surface has advantages over a circular surface, as the applications can be made without overlapping or leaving intervening spaces. This was pointed out some time ago by the late Mr. Hartigan. But there are many cases where the corners of a rectangular applicator would be inconvenient, and at the present price of radium there will be few who will be able to afford radium applicators of varied form. For those cases where the affected area is extensive and little penetration is required, I have found that aluminium foil (known in the trade as " 0.004 to 0.008 ") is useful. The foil can be cut to the required shape, and if heated to dull redness and allowed to cool slowly, can be moulded to the surface of the part which is being treated. The ordinary radium box applied to this foil renders the foil radio-active throughout its extent, and the same effect is produced as by spreading the radium. Again, where greater penetration is required, it is surely reasonable to expect greater power of penetration from a focus where the radium salt is concentrated than when the salt is spread over a surface, and, as it were, diluted. The power of penetration will diminish in ratio to the extent to which the radium salt is spread. This is shown by the fluorescent screen, on the proof-plane, and by the electroscope.

It appears to me, therefore, that at the present time, and in the present scarcity of radium, the first-devised form of radium box still has its advantages. It can be used with aluminium foil in the manner I have described. It can be placed in a test-tube and thus applied in hollows and cavities. Where there are nodules of malignant growth to be seen, such as those appearing in a scar after operation, the rays from a focus of radium can be brought to bear upon each nodule. And where the disease is more deeply seated, as in the substance of the breast, by simply applying the box of radium in different situations upon the breast surface for short periods of, say, 10 to 15 minutes that action of deeply penetrating rays can be obtained which has been dignified by the special designation of "cross-fire."

I am, Sir, yours faithfully,

¿Ashley-place, s.W., May $22 n d, 1909 . \quad$ R. BRowne-Carthew.

\section{THE BUDGET AND MEDICAL PRACTITIONERS.}

To the Editor of THE LANCET.

Sir,-I presume that Dr. Clement Dukes is not a motorist. The attitude he adopts in the letter which you publish in to-day's issue is calculated to considerably injure those of our profession who do their work by car instead of by horse traction. The Chancellor of the Exchequer has realised that the motoring doctor deserved lighter treatment than the wealthy tourist, but Dr. Dukes would scorn such consideration.

Let us examine his alternative proposals: 1 . That the honorary staffs of hospitals should receive fees for attendance at inquests. This in a town of 210,000 inhabitants would amount to about $£ 5$ divided up between ten men out of the 120 practising here, of whom 17 at least are motorists and who will have to contribute at least an extra $\$ 5$ apiece per annum to the exchequer through the petrol tax, a total of $£ 85$ as compared with $£ 5$ under Dr. Dukes's proposal. 2. The amended laws of death certification recommended by Dr. Dukes would entail additional work which would be probably barely covered by the fee. 3. As regards the proposed remuneration of resident medical officers for attendance at inquests, having held in the past such appointments for two years, I may venture to say that the forensic experience thus gained early in professional life more than repays one for the trouble.

Finally, may I ask if Dr. Dukes realises that if automobilism advances as it has been doing up to the introduction of this Budget, in eight or ten years' time half the profession will be able to afford cars, to the great benefit of themselves and their patients.

Southsea, May 22nd, 1909. I am, Sir, yours faithfully,

\section{A FATAL CASE OF POISONING BY VERONAL. \\ To the Editor of THE LANCET.}

SIR, - The following notes may interest your readers, as they refer to the fatal case of veronal poisoning to which you alluded in your issue of May $22 \mathrm{nd}$.

A man, aged 40 years, who had for some weeks been in the habit of taking veronal for sleeplessness, in doses varying between 10 and 30 grains, being probably desirous of sleeping through the whole of a certain day, about the midnight previously took 10 half-gramme tablets and two cachets of 12 grains each, a total of 99 grains. Half an hour afterwards he experienced severe abdominal pain, but in an hour he was fast asleep. I first saw him 17 hours after he had taken the drug. He was then quite comatose ; pinching, pressure on the supra-orbital nerve, \&c., failed to produce any reaction. The pulse, full and bounding, was 120 . Temperature $99^{\circ} \mathrm{F}$. in axilla. Respiration 24. Pupils moderately dilated and reacting to light, but no conjunctival reflex. Skin hot and dry. He had passed a large quantity of urine into the bed. A small quantity obtained by catheter and tested showed a faint trace of albumin, specific gravity 1020 , rather high-coloured, but not of the reddish tinge associated with hæmatoporphyrinuria. From this time onward to the time of his death the pulse gradually quickened to 150 and was easily counted. The temperature taken again 24 hours after the drug had been taken, rose to $101^{\circ}$ in the axilla, and a few hours before death was $104{ }^{\circ}$ in the axilla. The respiratory rate quickened to 32,24 hours from onset, and then remained almost constant until a few hours before death, when it rose, coincidently with the onset of pneumonic congestion, to 44 . 20 hours after taking the dose a thin, frothy, light-yellow, sweetish-smelling discharge began to exude from the mouth and continued profusely until death, necessitating constant clearing of the mouth and pharynx. The urine was passed at intervals in considerable quantity. That obtained by 
catheter 48 hours from the onset showed the same features as mentioned above, and as far as $I$ could ascertain without spectroscopic examination contained no hæmatoporphyrin. For the last 12 hours sweating was profuse. Death occurred 53 hours after taking the overdose, there having been no return to consciousness from the first onset of sleep. The treatment adopted was purely stimulating. Being called so late to the case emptying the stomach was futile. Strychnine, brandy, and digitalin were alternately injected hourly. To diminish the excretion of the mouth and throat atropine sulphate 1-100th grain was injected without apparent effect. I am, Sir, yours faithfully,

F. E. WALKER, M.B., B.S. Lond.

Uxbridge, May 22nd, 1909.

\section{SMOKE ABATEMENT.}

Io the Editor of THE LANCET.

SIR,-In the remarks in THE LANCET of May 15th with regard to smoke abatement it is noticeable that no allusion is made to one of, it appears to me, the most obvious and best of methods of preventing London fogs, that is, the substitution of smokeless fuels for coal as at present used. Both anthracite coal and coalite provide the advantages of open fires and are, I believe, as efficient for heating and cooking as ordinary coal. Any observant householder could satisfy his mind on this question by the trial of one or of both. The reduction of sunlight and the ill effects produced in various ways on the health of the inhabitants of London and other large cities by smoke, as well as the drawback to trade which fogs occasion, afford good reasons for using every endeavour to prevent them.

White fogs are seen in New York, but the smoke nuisance is, I am told, unknown, and the only reason for its absence appears to be the greater use of hot-water coils, gas, electricity, and of anthracite or other smokeless coal. With by-laws which prevent those living in houses rented at $£ 200$ per annum or above from burning ordinary coal in the first year of their institution, and those living in houses at a rental of $£ 50$ less similarly treated in the second year, and so on, in five years the capital would be rid of smokeemitting chimneys. If, then, London can be relieved of the ban of smoke-laden fogs, with which it has been inflicted for many generations, by ensuring the use of smokeless fuel in all houses in a certain mapped-out area in the first instance, and later in factories, \&c., why wait much longer before adopting the necessary measures?

Oxford, May 17th, 1909. I am, Sir, yours faithfully, A. Stayt Dutron.

\section{ACUTE RHEUMATISM AND TONSILLITIS.} 7o the Editor of THE LANCET.

SIR,-The association of rheumatic fever and tonsillitis is well known, but is one which is often difficult to prove. Recently I have been attending two cases of tonsillitis and pharyngitis in the same household, one of the patients being a girl of 19 and the other a little girl of four years of age. The attack started as a pharyngitis and tonsillitis in both instances and almost simultaneously, the main character of the local inflammation being a dusky redness of the tonsils and fauces, associated with pain on swallowing. The temperature was $101^{\circ} \mathrm{F}$. in both, tending to rise in the child to $102^{\circ}$ and more in the evening; there was definite tenderness along the tibix and of the ribs, and a soft systolic murmur at the apex in the child, indicating endocarditis. The older girl complained of marked tenderness " all over," but mostly in the joints of the wrist and elbow, and pain on movement; in her case no systolic murmur could be detected. There was no marked swelling or redness of the joints in either case. I quote these two instances arising in the same house in order to emphasise the following points : 1 . The infectious nature of the complaint. 2. The fact that the tonsils and pharynx are probably the most frequent sites of primary infection and transmission to other parts (endocardium, \&c.). 3. The character of the pharyngeal and tonsillar inflammation (dusky red, no patches of secretion or sloughing). 4. The frequency with which these "throats" are diagnosed as simple tonsillitis and pharyngitis (due to ordinary pyogenic organisms). 5. The importance of careful examination of the cardiac area, especially in children in whom the symptoms of a mild pharyngitis are associated with bone and joint tenderness.

Both Osler ${ }^{2}$ and Goodhart and Still ${ }^{2}$ emphasise the frequency of the origin of acute rheumatism as a "sore throat." I also remember a case at the Essex County Hospital where a young man who was admitted for the same association of symptoms developed marked mitral and aortic disease which resulted in chronic disease of the mitral and aortic valves.

I am, Sir, yours faithfully,

H. A. Haig, M.B., B.S. Lond., M.R.C.S. Fing.

Hendon, N.W., May 24th, 1909.

\section{ENUCLEATION OF THE TONSIL.}

\section{7o the Editor of THE LANCET.}

SIR,-I read with much interest the article by Dr. G. E. Waugh on enucleation of the tonsil in your issue of May 8th, as during the past 12 months I have performed at the Eye and Ear Hospital, Croydon, over 100 enucleations, the majority being in adults, and so can testify both to the simplicity of the procedure and also to its comparative bloodlessness. 'There was one point to which no reference was madenamely, the plica triangularis, which, especially in adults, owing to some shrinkage of tonsillar tissue, is easily mistaken for the anterior pillar. It is often adherent to the tonsil, and an incision made just posterior to the plica would enter tonsillar tissue and instead of exposing the capsule, which is the quintessence of the operation, it would cause such hæmorrhage as to render enucleation practically impossible. Whether spasm of the glottis be due to traction on the posterior pillar or not is a contentious point, and personally I have rarely been able, after control of the hæmorrhage, to excite any spasm by such traction.

I am, Sir, yours faithfully

JAS. ForRest, M.B., F.R.C.S. Edin.

Croydon, May 18th, 1909

\section{AN APPEAL TO LIBRARIANS AND BO0K COLLECTORS.}

To the Editor of THE LANCET.

SIR, - In connexion with the first meeting of the Medical Library Association to be held in Queen's College, Belfast, during the last week in July, a loan exhibition will be held illustrating medical libraries and medical literature.

Amongst other things, we are particularly anxious to receive the following: (1) MSS. and early printed books (2) first editions of noteworthy books ; (3) early Irish printed books (there are few, if any, before 1700 ); (4) books on tuberculosis; (5) books upon Celtic medicine; (6) photographs of libraries; (7) statistical diagrams giving number of volumes, issues, readers, income, \&c. ; and (8) library papers, rules, \&c

The association will insure all loans and the exhibits will be most carefully guarded. We venture to hope for early and favourable replies, as the time for the preparation of the exhibit is rather short.

We are, Sir, yours faithfully,

I. WALKER HALI

CuthBERT E. A. Clayton, $\}_{\text {Secretaries, }}$ May 17th, 1909

Medical Library Association, the University, Manchester.

\section{MEDICAL MEN AND THE CLERGY IN RELATION TO "CHRISTIAN SCIENCE." \\ To the Editor of THE LANCET.}

SIR,-It is perfectly obvious that you are opposed to the teachings of Christian Science, but that is no reason why, when an attack upon Christian Science is reported in you columns, you should hesitate to extend to the person attacked the courtesy extended to the attacker. It is, on the contrary, an additional reason for the extension of your courtesy to the attacked. In these circumstances you will I think, permit me to take exception to the tone and reasoning of Mr. Stephen Paget's criticism of Christian Science.

It has been said, and said with reason, that when a man

I Osler : Principles and Practice of Medicine, 1907. 2 Goodhart and Still : Diseases of Children, 1905. 